Journal of Advanced Research in Fluid Mechanics and Thermal Sciences

\title{
Effects of Ethanol Blending with Methanol-Gasoline fuel on Spark Ignition Engine Performance and Emissions
}

\author{
Mohamad Qayyum Mohd Tamam ${ }^{1,2}$, Nik Rosli Abdullah ${ }^{1,}{ }^{*}$, Wira Jazair Yahya ${ }^{2}$, Hasannuddin Abdul \\ Kadir $^{3}$, Yanuandri Putrasari ${ }^{4}$, Mohd Azrul Ahmad ${ }^{1}$

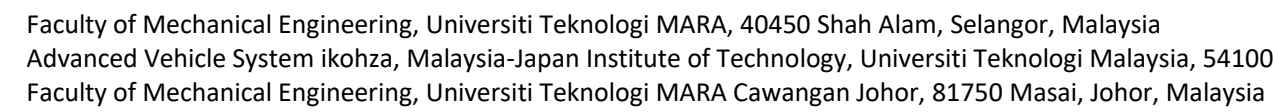

\section{Article history:}

Received 17 December 2020

Received in revised form 20 April 2021

Accepted 2 May 2021

Available online 15 June 2021

\section{Keywords:}

Alternative fuels; engine performance; ethanol; exhaust emission; methanol; spark ignition
This research investigated the effects of ethanol blending with methanol-gasoline as fuels in spark ignition engine and how it affects engine performance and emissions. Four ethanol-methanol-gasoline (GEM) blends were prepared with variable ethanol concentrations $(0 \%, 5 \%, 10 \%, 15 \%)$ and constant methanol concentration (10\%) and denoted as M10, E5M10, E10M10, and E15M10 in reference to each respective alcohol constituents. Physicochemical properties testing revealed that density and kinematic viscosity of GEM fuel blends increases with ethanol concentration. E15M10 has shown the most increase in density and kinematic viscosity with $10.7 \%$ and $18.7 \%$ increase respectively. In contrast, calorific value decreased as ethanol concentration decreases. E15M10 displayed the lowest calorific value at $16.9 \%$ lower than gasoline. Meanwhile, engine performance and emissions test showed that GEM fuels generally possess increased average Brake Thermal Efficiency (BTE) than pure gasoline. However, average Brake Specific Fuel Consumption (BSFC) for pure gasoline is lower. E15M10 displayed highest increment of BSFC at $17.2 \%$ average increase. Meanwhile, E10M10 displayed the highest improvement in BTE with an average of 9.4\% increase. Exhaust emissions indicate that all GEM blends produced increased carbon dioxide $\left(\mathrm{CO}_{2}\right)$ and oxides of nitrogen (NOx) emissions while carbon monoxide (CO) emissions decreases. E15M10 showed the most reduction in $\mathrm{CO}$ emissions with $90.6 \%$ decrease while E10M10 has shown the most increased $\mathrm{CO}_{2}$ and $\mathrm{NOx}$ emissions with $110 \%$ and 6.7 times increase respectively. In conclusion, up to $15 \%$ volume of ethanol blending with $10 \%$ volume methanol-gasoline was able to improve engine performance and emissions in terms of BTE and CO emissions.

\section{Introduction}

Carbon-based emissions are one of the main products of fossil fuel combustion process in automobile internal combustion engines. It is one of a group of environmentally hazardous gases called greenhouse gases (GHG), and emission of these gases into the atmosphere contributes to

\footnotetext{
* Corresponding author.

E-mail address: nikrosli@uitm.edu.my

https://doi.org/10.37934/arfmts.83.2.5472
} 
climate change [1]. U.S. Environmental Protection Agency (EPA) has found that transportation sector accounts for majority of GHG emissions [2] and particulate matter emissions, specifically diesel engines [3]. Furthermore, fossil fuel sources are depleting [4] and several studies suggested that current petroleum reservoirs are able to accommodate for global demands for the next 39 years [5] as global petroleum demand surpassed petroleum production worldwide [6]. Therefore, amid dwindling petroleum sources, alternative fuels need to be fully utilised in order to meet growing energy demands.

Hence, numerous researches into alternative fuels have been carried out to examine the viability of renewable alternatives for fossil fuels which possess better emission characteristics while not compromising on performance. Several alternative fuels have garnered attention in recent years, among them include biodiesel, dimethyl ether (DME), hydrogen, natural gas, and alcohols.

One of the most comprehensively studied alternatives is the usage of alcohols either as substitute to fossil fuel or as an additive in fossil fuels to improve combustion performance and emissions. Alcohols are any organic compounds in which a hydroxyl functional group (-OH) is attached to a carbon atom [7] and the general chemical structure of alcohols are denoted by the formula $\mathrm{CnH} 2 \mathrm{n}+1 \mathrm{OH}$. Alcohols burn homogeneously and emits largely smaller pollutants and particulate matters due to the presence of oxygen in the hydroxyl functional group [8,9]. Gasoline on the other hand, is a compound hydrocarbon which emits combustion by-products such as carbon monoxide (CO), carbon dioxide $\left(\mathrm{CO}_{2}\right)$, unburned hydrocarbon $(\mathrm{UHC})$, and oxides of nitrogen $\left(\mathrm{NO}_{\mathrm{x}}\right)$. Other key contributing factors which influence lower emissions in lower molecular mass alcohols such as methanol and ethanol, includes faster flame speed and absence of Phosphorus and Sulphur elements in its constituents [10].

Methanol is the simplest alcohol, with chemical formula of $\mathrm{CH}_{3} \mathrm{OH}$. It is synthesized using natural gas and coal as feedstock, and from biomass sources mainly using wood feedstock [11]. In terms of methanol production, natural gas is the main source of feedstock, accounting to approximately $65 \%$ of total global methanol production and less than $1 \%$ of production using biomass feedstock [12]. Recent research on methanol production has shown that it is possible to synthesize methanol from carbohydrates by means of gasification by partial oxidation [13] and therefore sources like rice and sawdust can be viable candidates for methanol production by this method. Nonetheless, Methanol is conventionally produced using synthesis gas produced from natural gas and coal [14].

Ethanol or Ethyl Alcohol is the second simplest alcohol, with chemical formula of $\mathrm{C}_{2} \mathrm{H}_{6} \mathrm{OH}$. There are two major ways to produce ethanol, the first is by reacting ethane with steam [15], while the second method is via fermentation of sugars or biomass containing lignocelluloses [16]. Feedstocks used for ethanol production are agricultural crops which can be categorized into three categories: (i) sugar feedstocks from sugar beet and sugar cane, (ii) starch feedstocks from wheat, corn, and barley, and (iii) cellulosic feedstocks from wood, sawdust, and grass [17]. In terms of ethanol production worldwide, the two largest ethanol-producing countries are the U.S. and Brazil, and the main crops used for feedstock are maize and sugar cane respectively for both countries [15]. In 2018, the U.S. has produced 16,061 million gallons of ethanol or $56 \%$ of global ethanol production while Brazil has produced 7,920 million gallons which contributes to $28 \%$ of total production worldwide [18].

Both methanol and ethanol are considered as lower mass alcohols and its physicochemical properties varies quite substantially as compared to pure gasoline. Table 1 describes the physicochemical properties of methanol, ethanol, and pure gasoline. 


\section{Table 1}

Physicochemical properties of methanol, ethanol, and pure gasoline [19]

\begin{tabular}{llll}
\hline Properties & Gasoline & Methanol & Ethanol \\
\hline Chemical Formula & $\mathrm{C}_{5-10 \mathrm{H}_{12}-22}$ & $\mathrm{CH}_{3} \mathrm{OH}$ & $\mathrm{C}_{2} \mathrm{H}_{5} \mathrm{OH}$ \\
Molecular weight mass (\%) & 106.22 & 32.04 & 46.7 \\
Carbon mass (\%) & 87.5 & 37.5 & 52.2 \\
Hydrogen mass (\%) & 12.5 & - & 34.7 \\
Oxygen mass (\%) & 0 & 49.93 & 34.7 \\
Density (g/cm3) & 0.737 & 0.792 & 0.785 \\
Boiling temperature $\left({ }^{\circ} \mathrm{C}\right)$ & $27-225$ & 78 & 78.25 \\
Reid Vapor Pressure $(\mathrm{kPa})$ & $53-60$ & 32.4 & 17 \\
Research Octane Number, $\mathrm{RON}$ & $90-100$ & 108.7 & $108.6-110$ \\
Motor Octane Number, $\mathrm{MON}$ & $82-92$ & 86.6 & 92 \\
Latent Heat of Vaporisation $(\mathrm{kJ} / \mathrm{kg})$ & 349 & 920 & 923 \\
Lower Heating Value $(\mathrm{MJ} / \mathrm{kg})$ & 44.0 & 20.1 & 26.9 \\
Freezing point $\left({ }^{\circ} \mathrm{C}\right)$ & -40 & -97.5 & -114 \\
Viscosity $(\mathrm{mm} 2 / \mathrm{s})$ & $0.5-0.6$ & 0.596 & $1.2-1.5$ \\
Flash point $\left({ }^{\circ} \mathrm{C}\right)$ & -45 to -13 & 11 & $12-20$ \\
Autoignition temperature $\left({ }^{\circ} \mathrm{C}\right)$ & 257 & 423 & 425 \\
\hline
\end{tabular}

Both methanol and ethanol have higher oxygen content at $49.93 \%$ and $34.7 \%$ respectively compared to pure gasoline and therefore promotes a more complete fuel combustion and reduces harmful exhaust emissions [20]. Furthermore, higher Research octane number (RON) of methanol and ethanol prevents engine knocking resulting from premature ignition. In addition, lower heating value (LHV) of methanol and ethanol are less than pure gasoline, therefore higher fuel consumption is expected for both alcohols. Moreover, higher densities observed for both alcohol fuels increases volumetric fuel economy [20]. Higher viscosities of methanol and ethanol might affect automobile fuel injection system owing to increased flow resistance under low temperatures [21]. While generally associated as fuel in spark ignition engines, ethanol has received interest as a low reactive fuel in combination with diesel in Reactivity Controlled Compression Ignition ( $\mathrm{RCCl}$ ) engines [22].

To date, most literature have focused on single alcohol-gasoline blends. Previous research on methanol-gasoline blends revealed increased engine torque and power [23], reduced $\mathrm{CO}$ and $\mathrm{NO}_{x}$ emissions [24] as well as decreased particulate emissions [25]. In contrast, volatile organic compounds (VOC) and carbonyl emissions increased with introduction of methanol to gasoline [26]. On the other hand, ethanol-gasoline blends reported decreased $\mathrm{UHC}, \mathrm{CO}, \mathrm{CO}_{2}$, and $\mathrm{NO}_{\mathrm{x}}$ emissions [27-30] while BSFC and engine torque increased [31]. Butanol-gasoline also displayed similar reductions in $\mathrm{UHC}, \mathrm{CO}, \mathrm{CO}_{2}$, and $\mathrm{NO}_{\mathrm{x}}$ emissions $[32,33]$. However, some research reported reductions in engine torque, power and volumetric efficiency [34] while others reported higher efficiency was achieved at lower throttle position [35].

Few literatures have documented the effects of dual-alcohol blends or more, specifically ethanolmethanol-gasoline blends (GEM) blends. Turner et. al., [36] have investigated the potential of GEM blends as a substitute for E85/gasoline fuels in flex fuel vehicles (FFV). It is found that such blends have stable octane numbers, enthalpies of vaporization, and volumetric energy content while being stoichiometrically equivalent to E85 blends. Furthermore, the GEM blends have shown 5\% increase in vehicle energetic efficiency and reduction in $\mathrm{CO}_{2}$ emissions. Sileghem et. al., [37] also investigated on GEM blends which are stoichiometrically equivalent to E85 and found out that BTE increased as compared to gasoline, however it is less than pure methanol and higher than pure ethanol. Elfasakhany [38] has experimented with different GEM blend ratios while maintaining the same vol\% of both ethanol and methanol for each respective blend. Results indicate that $\mathrm{CO}$ and UHC emission for GEM blends is reduced as compared to pure gasoline, but higher than methanol blends and lower 
than ethanol blends. The same trend is observed for volumetric efficiency and torque. Similarly, Nazzal [39] has investigated the effects of various alcohol blends on a typical SI engine using methanol-gasoline, ethanol-gasoline, and GEM blends. As with the case with Elfasakhany [38], vol\% of ethanol and methanol remained constant in the GEM blends tested. Experimental results shown that BTE and Brake Power for GEM blends are higher than gasoline and ethanol-gasoline, but lower than methanol-gasoline blend.

Therefore, based on the results from Elfasakhany [38], Sileghem et al., [37] and Nazzal [39], GEM blends in general have better performance and emissions characteristics than ethanol blends and gasoline, but less than methanol. It is important to note that Turner et. al., [36] and Sileghem et. al., [37] used GEM blends which are stoichiometric air fuel ratio (AFR) equivalent to E85 and did not emphasize on how the different alcohol concentrations affect the engine performance and emissions. Elfasakhany [38] and Nazzal [39] on the other hand, studied on the effects of different methanol and ethanol blends, however for each GEM blend, the ratio of methanol and ethanol to gasoline remains constant. For instance [38], a ternary-alcohol blend named EM10 used in his experiment has the ratio of ethanol-methanol-gasoline given by 5:5:90. Thus, there has been no conclusive study to date which have addressed how different $\% \mathrm{v} / \mathrm{v}$ of ethanol blending would affect engine performance and emissions at constant methanol \% v/v.

Present study seeks to examine the effects of variable ethanol \% v/v blending with constant methanol $\% \mathrm{v} / \mathrm{v}$ towards overall fuel blend physicochemical properties, as well as their effects on spark ignition (SI) engine performance and emissions. In this study, various ethanol blend ratio between $5 \%$ to $15 \%$ $\mathrm{v} / \mathrm{v}$ were blended with constant $10 \% \mathrm{v} / \mathrm{v}$ of methanol, while commercial R100 gasoline was used as base fuel. Physicochemical properties such as kinematic viscosity, density, and calorific value (CV) of the blended fuels were measured in accordance to ASTM standards. Furthermore, engine performance tests were carried out on a single cylinder SI generator engine to investigate Brake Specific Fuel Consumption (BSFC), Brake Thermal Efficiency (BTE) and exhaust gas emissions such as $\mathrm{CO}, \mathrm{CO} 2$, and NOx for each blends in comparison to pure R100 gasoline.

\section{Methodology}

\subsection{Selection of Alcohol Fuels}

Types of alcohols selected for this research consists of methanol and ethanol. Methanol is obtained from SYSTERM Chemicals with minimum $99.8 \%$ purity while ethanol is obtained from R\&M Chemicals with minimum $95 \%$ purity. These alcohols are of analytical reagent grade and conforms to American Chemical Society (ACS) standard. Meanwhile, base fuel selected for alcohol blending is Petron Blaze 100 Euro 4M procured from Petron Malaysia.

Four GEM blends with varying ethanol additive concentrations were specified and blended in accordance to blend ratios specified in Table 2 . The test blends used in the experiments were named as M10, E5M10, E10M10, E15M10 in accordance to volume \% of each alcohol additive. Each fuel component was measured and blended together in a container using a mechanical mixer at speed of $400 \mathrm{rpm}$ for 30 minutes before it was stored separately in a closed High-Density Polyethylene (HDPE) jerry container. This was done to prevent fuel evaporation since gasoline and alcohols may evaporate at ambient temperature. Furthermore, each test fuels were once again mechanically mixed at 400 rpm for 15 minutes and left for another 15 minutes each time before feeding the fuels to the engine. This was done in order to allow the mixture to reach equilibrium before testing as well as to prevent any possibility of phase separation between methanol-ethanol-gasoline when the mixture is kept for a long time. The aforementioned procedures were done in reference to preparation methods of previous researches on alcohol-gasoline fuels $[11,20,40]$. 


\subsection{Measurement of Physicochemical Properties}

In this research, three physicochemical properties were considered for analysis which consisted of density, CV, and kinematic viscosity. The properties were measured using specified equipment in accordance to established ASTM standards as indicated in Table 3.

Table 2

Volume concentrations of methanol, ethanol, and gasoline for all test blends

\begin{tabular}{llll}
\hline Test Blend & Volume of methanol (vol\%) & Volume of ethanol (vol\%) & Volume of gasoline (vol\%) \\
\hline M10 & 10 & - & 90 \\
E5M10 & 10 & 5 & 85 \\
E10M10 & 10 & 10 & 80 \\
E15M10 & 10 & 15 & 75 \\
Pure Gasoline & - & - & 100 \\
\hline
\end{tabular}

Table 3

Equipment and procedures used for physicochemical properties measurement

\begin{tabular}{|c|c|c|c|}
\hline $\begin{array}{l}\text { Physicochemical } \\
\text { Property }\end{array}$ & Measuring Equipment & Manufacturer & Standard procedure \\
\hline $\begin{array}{l}\text { Density at ambient } \\
\text { temperature }\left(\sim 27^{\circ} \mathrm{C}\right)\end{array}$ & $\begin{array}{l}\text { AUW } 320 \text { Analytical } \\
\text { Balance }\end{array}$ & $\begin{array}{l}\text { Shimadzu } \\
\text { Corporation }\end{array}$ & - \\
\hline Calorific Value & $\begin{array}{l}\text { C5000 Automated } \\
\text { Calorimeter }\end{array}$ & IKA Works & ASTM D240 \\
\hline Kinematic Viscosity & $\begin{array}{l}\text { HVM } 472 \text { Multirange } \\
\text { Viscometer }\end{array}$ & PAC L.P & ASTM D445 \\
\hline
\end{tabular}

Densities of all test fuels were measured using AUW 320 Analytical Balance. In order to measure density, a small beaker was placed onto weighing pan of the analytical balance and was set to zero. Following that, $1 \mathrm{~cm} 3$ of sample fuel was drawn using disposable syringe before being injected into the small beaker. Glass doors surrounding the weighing chamber were closed to prevent disturbance from surrounding air. Mass reading from the display panel was recorded once the reading has stabilized and this procedure was repeated three times to ensure consistent results.

CV for each test fuels was determined by adiabatic jacket method using C5000 Automated Calorimeter in compliance with ASTM D240 standard [41]. $1 \mathrm{~g}$ of fuel sample was drawn and weighed using an analytical balance before it is transferred to a crucible for temporary storage. Afterwards, a cotton thread was secured on the ignition wire located on the bomb cover, and the crucible was placed on the crucible holder. The open end of the cotton thread was then suspended into the crucible where it touches the sample to ensure ignition during testing. Subsequently, $1 \mathrm{~cm}^{3}$ of water was added into the decomposition vessel, and the bomb cover was screwed tightly onto the decomposition vessel before being inserted into the calorimeter setup for testing. The bomb was then charged with oxygen at $30 \mathrm{~atm}$ gage pressure before sample ignition. Temperature rise in the adiabatic jacket calorimeter was measured and the resultant CV was calculated using proprietary software.

Kinematic viscosity was determined by using an HVM 472 Multirange Viscometer in accordance to ASTM D445 standard [42]. Desired bath temperature was set at $30^{\circ} \mathrm{C}$ and was left to stabilized. Once bath temperature stabilized, $10 \mathrm{~cm}^{3}$ of sample fuel was drawn and placed in a sample beaker. The sample beaker was then inserted into the sample feeder and testing was initiated. Fuel sample was fully pumped through the capillary tube and allowed to flow under gravity. Flow time was 
recorded, and kinematic viscosity was automatically calculated as a function of flow time and viscometer calibration constant.

\subsection{Engine Experimental Setup}

Engine used in this research was a single cylinder, 4-stroke SI generator engine (Yamaha MZ175) without any modifications. Engine setup schematics is illustrated in Figure 1 while engine specifications are as detailed in Table 4.

The engine shaft was connected directly to a brushless alternator generator unit without any difference ratio of speed, which provides alternate current (AC) output for electrical applications. Specifications for the generator are explained in Table 5. Using this feature, various electrical loads were applied to the engine to simulate mechanical load in the form of applied torque. Engine speed is verified at the generator rotor, and it is assumed that no connecting losses occur between the engine and generator rotor.

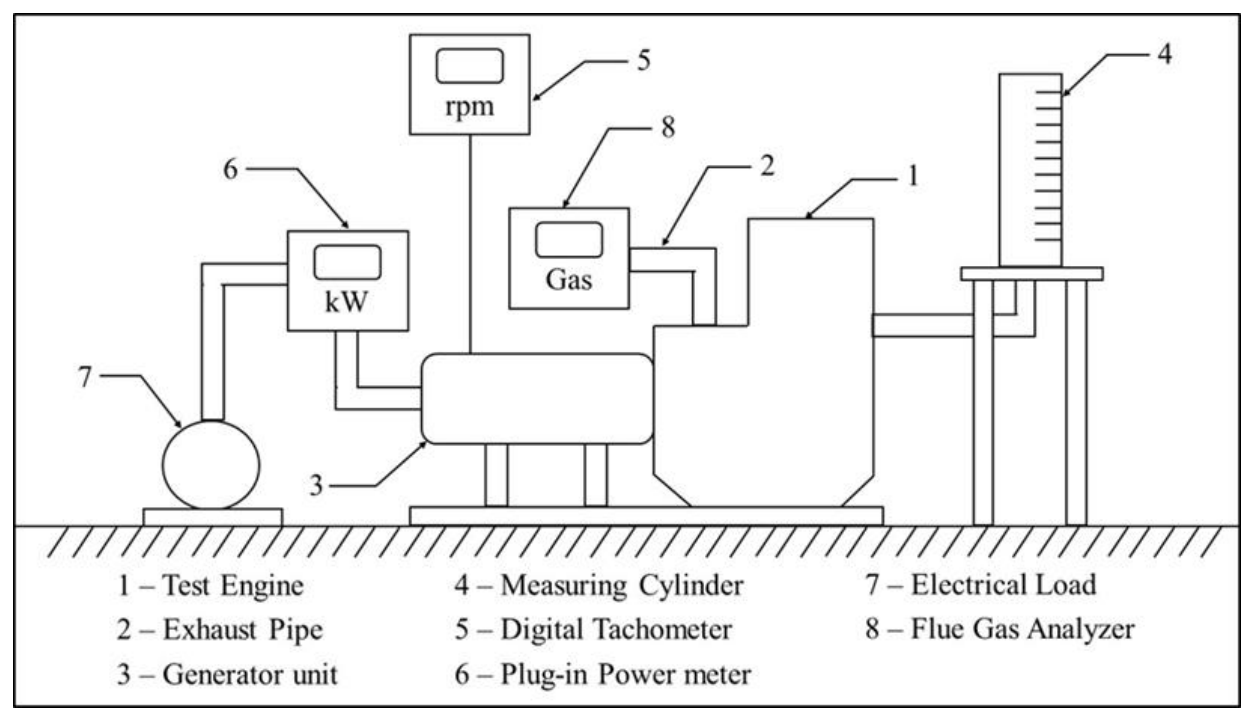

Fig. 1. Schematic diagram of experimental setup

Table 4

Engine setup specifications

\begin{tabular}{ll}
\hline Engine Parameters & \\
\hline Model & Yamaha MZ175 \\
Bore X Stroke & $66 \times 50 \mathrm{~mm}$ \\
Displacement & $171 \mathrm{~cm} 3$ \\
Compression Ratio & $8.5: 1$ \\
Intake system & Naturally aspirated \\
Fuel system & Carburetor \\
Maximum Power & $3.5 \mathrm{~kW}$ at 3600 rpm \\
Rated Power & $3.0 \mathrm{~kW}$ at 3600 rpm \\
Maximum Torque & $10.5 \mathrm{Nm}$ at 2400 rpm \\
Ignition System & Transistor Controlled Ignition \\
Lubrication System & Mechanical Splashing \\
\hline
\end{tabular}




\section{Table 5}

\begin{tabular}{ll} 
Generator specifications & \\
\hline Generator Specifications & \\
\hline Model & EFL2600V699 \\
Alternator & Brushless $\leq 5 \%$ T.H.D \\
Rated AC output & $2.1 \mathrm{kVA}$ at $3000 \mathrm{rpm}$ \\
Maximum AC output & $2.3 \mathrm{kVA}$ at $3000 \mathrm{rpm}$ \\
Voltage & $230 \mathrm{~V} / 50 \mathrm{~Hz}$ \\
\hline
\end{tabular}

Prior to conducting the experiments, the test engine was started and warmed up for 15 minutes using pure gasoline. Afterwards, engine was shut down and pure gasoline was drained from the measuring cylinder and replaced with the test fuel. The engine was then restarted and allowed to run until $5 \mathrm{~cm} 3$ of the test fuel was consumed. This was done to account for residual pure gasoline left in the fuel line upon draining. Once engine oil and intake air temperature stabilized within the range of $50 \pm 3^{\circ} \mathrm{C}$ and $33 \pm 3{ }^{\circ} \mathrm{C}$ respectively, engine speed was adjusted to $3000 \mathrm{rpm}$ and various electrical load was applied to the engine set at $25 \%, 50 \%$, and $75 \%$ from rated AC power of the engine generator. Mass flow rate of fuel was recorded in order to calculate for BSFC and BTE, while exhaust emissions of $\mathrm{CO}, \mathrm{CO}_{2}$, and $\mathrm{NO}_{x}$ were measured using gas analyser. The test was performed three times for each fuel blend to obtain an average value.

\subsection{Engine Experimental Calculations}

\subsubsection{Brake specific fuel consumption}

BSFC is calculated using the following formula given in Eq. (1) [43]

$B S F C=\frac{\dot{m}_{f u e l}}{P_{b}}$

where $\dot{\mathrm{m}}_{\text {fuel }}$ is the mass flow rate of fuel measured in $(\mathrm{g} / \mathrm{h})$ and $\mathrm{P}_{\mathrm{b}}$ is the brake power of the engine measured in $(\mathrm{kW})$

\subsubsection{Brake thermal efficiency}

Furthermore, BTE is calculated by using Eq. (2) and Eq. (3) [43]

$$
\begin{aligned}
& B T E, \eta_{\text {thermal }}=\frac{P_{b}}{\dot{m}_{f} C V} \times 100 \\
& B T E, \eta_{\text {thermal }}=\frac{3600}{B S F C(C V)} \times 100
\end{aligned}
$$$$
\text { or }
$$

where, BSFC is obtained from Eq. (1) measured in (g/kWh), and CV is obtained from experimental results measured in $(\mathrm{MJ} / \mathrm{kg})$. 


\subsection{Uncertainty Evaluation}

Experimental results are prone to errors resulting from various external and internal factors such as human error, calibration error, measurement error as well as inconsistent test conditions. Therefore, it is important to validate data collected from experiments for accuracy and consistency. In this research, data validation method utilised is via Relative Standard Error (RSE) \% as outlined by Zaharin et al., [44]. Calculations for RSE are as highlighted in Eq. (4)

$$
R S E=\frac{S E}{\bar{x}} \times 100 \%
$$

where, RSE is Relative Standard Error in percentage (\%), SE is Standard Error and $\bar{x}$ is mean of data. Meanwhile, Standard Error (SE) is given by the following Eq. (5)

$S E=\frac{\sigma}{\sqrt{n}}$

where $\Sigma$ is standard deviation of the data group and $\mathrm{n}$ is the number of data in the group. For each measurement parameter, a total of three readings are recorded and the RSE for each parameter are calculated.

Table 6 to Table 11 details the result of RSE values obtained for all measurement parameters. It is found that all measurement data has error of less than $15 \%$.

Table 6

RSE percentage for physicochemical properties of all test blends

\begin{tabular}{llll}
\hline \multirow{2}{*}{ Test Blend } & \multicolumn{2}{l}{ RSE \% of physicochemical property } \\
\cline { 2 - 4 } & Density & Calorific Value & $\begin{array}{l}\text { Kinematic } \\
\text { Viscosity }\end{array}$ \\
\hline Pure Gasoline & 3.33 & 0.66 & 0.44 \\
M10 & 1.22 & 0.95 & 5.06 \\
E5M10 & 1.37 & 0.68 & 6.55 \\
E10M10 & 4.21 & 0.42 & 2.84 \\
E15M10 & 3.03 & 0.98 & 4.49 \\
\hline
\end{tabular}

Table 7

RSE percentage for BSFC

\begin{tabular}{llll}
\hline \multirow{2}{*}{ Test Blend } & \multicolumn{3}{l}{ RSE \% at Engine Load } \\
\cline { 2 - 4 } & $25 \%$ & $50 \%$ & $75 \%$ \\
\hline Pure Gasoline & 3.57 & 0.42 & 1.68 \\
M10 & 2.63 & 2.95 & 1.68 \\
E5M10 & 1.93 & 0.49 & 0.64 \\
E10M10 & 0.43 & 1.10 & 0.83 \\
E15M10 & 1.77 & 1.65 & 1.53 \\
\hline
\end{tabular}


Table 8

RSE percentage for BTE

\begin{tabular}{llll}
\hline \multirow{2}{*}{ Test Blend } & \multicolumn{2}{l}{ RSE \% at Engine Load } & \\
\cline { 2 - 4 } & $25 \%$ & $50 \%$ & $75 \%$ \\
\hline Pure Gasoline & 3.69 & 0.42 & 1.69 \\
M10 & 2.70 & 2.96 & 1.69 \\
E5M10 & 1.96 & 0.50 & 0.65 \\
E10M10 & 0.43 & 1.10 & 0.83 \\
E15M10 & 1.75 & 1.63 & 1.52 \\
\hline
\end{tabular}

Table 9

RSE percentage for $\mathrm{CO}$ emissions

\begin{tabular}{llll}
\hline \multirow{2}{*}{ Test Blend } & \multicolumn{2}{l}{ RSE \% at Engine Load } \\
\cline { 2 - 4 } & $25 \%$ & $50 \%$ & $75 \%$ \\
\hline Pure Gasoline & 0.16 & 0.24 & 0.40 \\
M10 & 0.46 & 0.10 & 0.13 \\
E5M10 & 0.36 & 0.26 & 0.18 \\
E10M10 & 0.79 & 0.50 & 0.16 \\
E15M10 & 0.96 & 2.73 & 2.51 \\
\hline
\end{tabular}

Table 10

RSE percentage for $\mathrm{CO}_{2}$ emissions

\begin{tabular}{llll}
\hline \multirow{2}{*}{ Test Blend } & \multicolumn{3}{l}{ RSE \% at Engine Load } \\
\cline { 2 - 4 } & $25 \%$ & $50 \%$ & $75 \%$ \\
\hline Pure Gasoline & 2.88 & 2.70 & 2.29 \\
M10 & 3.49 & 0.48 & 1.25 \\
E5M10 & 1.23 & 1.34 & 2.18 \\
E10M10 & 2.56 & 0.98 & 0.92 \\
E15M10 & 1.98 & 1.34 & 0.71 \\
\hline
\end{tabular}

Table 11

RSE percentage for NOx emissions

\begin{tabular}{llll}
\hline \multirow{2}{*}{ Test Blend } & \multicolumn{3}{l}{ RSE \% at Engine Load } \\
\cline { 2 - 4 } & $25 \%$ & $50 \%$ & $75 \%$ \\
\hline Pure Gasoline & 5.00 & 7.22 & 6.11 \\
M10 & 14.29 & 1.37 & 2.31 \\
E5M10 & 7.14 & 0.00 & 0.61 \\
E10M10 & 1.00 & 0.29 & 0.47 \\
E15M10 & 3.78 & 0.36 & 0.27 \\
\hline
\end{tabular}

\section{Results and Discussion}

\subsection{Density}

Figure 2 illustrates visually the variation of density for methanol-gasoline, GEM blends and pure gasoline. It is evident that methanol-gasoline and GEM blends possess higher densities compared to pure gasoline. Pure gasoline is the least dense fuel at $0.772 \mathrm{~g} / \mathrm{cm}^{3}$ while E15M10 is the densest fuel at $0.854 \mathrm{~g} / \mathrm{cm}^{3}$. Moreover, densities of M10, E5M10, E10M10 and E15M10 increases at 1.7\%, 3.2\%, $7.8 \%$, and $10.7 \%$ respectively as compared to pure gasoline. Furthermore, it is noted that as concentration of methanol and ethanol in fuel blend increases, density of the fuel blends increases. This is due to methanol and ethanol having greater densities as compared to pure gasoline [24, 37, $38,45-50]$ and hence as the content percentage of alcohol in a fuel blend increases, the density of 
the blend would also increase. Consequently, higher mass fuels will cause higher fuel consumption due to higher fuel mass injected to the engine [51].

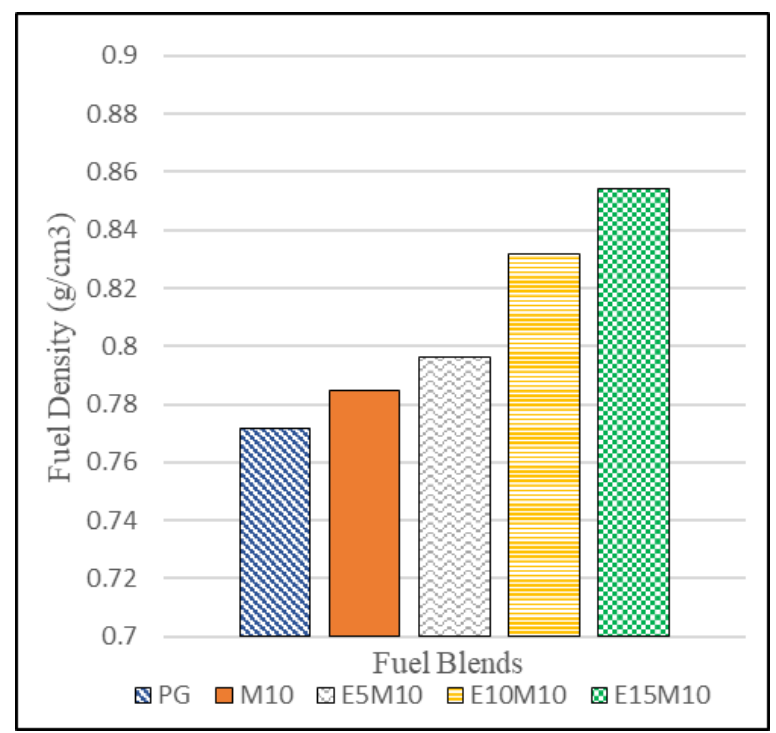

Fig. 2. Density variation for methanol-gasoline, GEM blends and pure gasoline

\subsection{Kinematic Viscosity}

Figure 3 presents the results of variation of kinematic viscosity for methanol-gasoline and GEM blends as compared to pure gasoline. Results have shown that methanol-gasoline and GEM blends possess higher kinematic viscosity as compared to pure gasoline. Pure gasoline is the least viscous of all test fuels at $0.558 \mathrm{~mm}^{2} / \mathrm{s}$ while E15M10 is the most viscous at $0.681 \mathrm{~mm}^{2} / \mathrm{s}$. Furthermore, kinematic viscosities of M10, E5M10, E10M10 and E15M10 increases at 8.1\%, 11.5\%, 16.2\%, and $18.7 \%$ respectively in comparison with pure gasoline. Hence, general trend across all test fuels shows that as concentration of ethanol and methanol in fuel blends increases, kinematic viscosity increases as well, similar as variation of density as discussed previously. Hence, with increasing fuel viscosity, higher energy will be required to pump the fuel affecting fuel economy [51]. Nonetheless, fuel pumps in gasoline engines operate at lower pressures as compared to diesel counterparts therefore fuel viscosity is rarely a major issue [20]. 


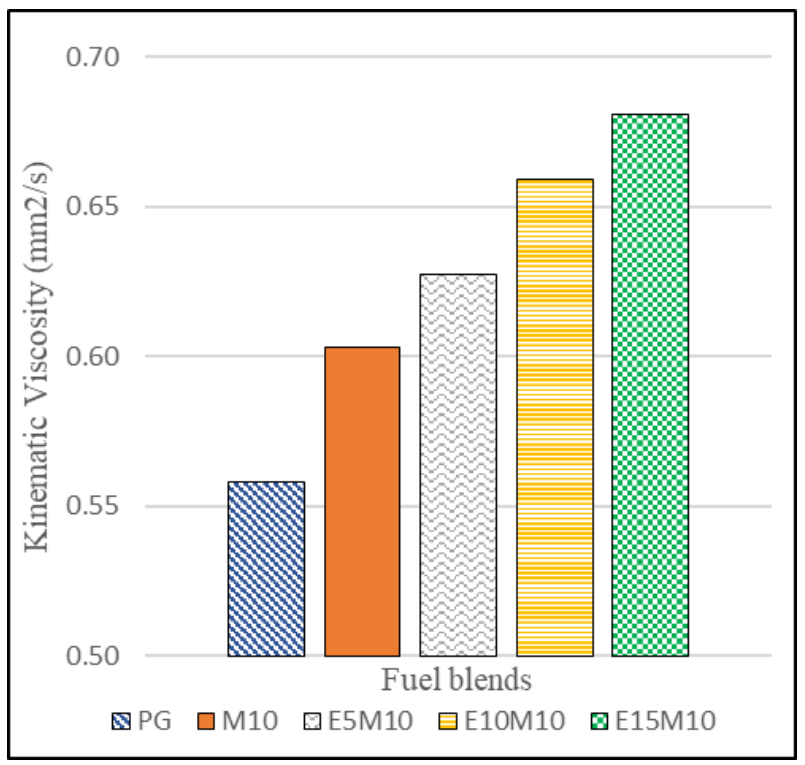

Fig. 3. Kinematic viscosity variation for methanolgasoline, GEM blends and pure gasoline

\subsection{Calorific Value}

Figure 4 displays comparison of CV for methanol-gasoline and GEM blends as compared to pure gasoline. It is found that pure gasoline possesses highest calorific value at $42.881 \mathrm{MJ} / \mathrm{kg}$ while E15M10 possess lowest calorific value at $35.616 \mathrm{MJ} / \mathrm{kg}$. CV of M10, E5M10, E10M10 and E15M10 decreases at $8.4 \%, 10.0 \%, 15.6 \%$, and $16.9 \%$ respectively in comparison with pure gasoline. Overall trend displays decrease of CV as ethanol values increases. Similar trends have been reported by Taib et al., [52] with increasing ethanol concentrations in ethanol-diesel blends. This is due to methanol and ethanol having less calorific value as compared to pure gasoline [24, 37, 38, 45-50] and thus reducing the overall blend calorific value with increasing proportion. This reduction in CV will cause fuel consumption to increase $[20,51]$.

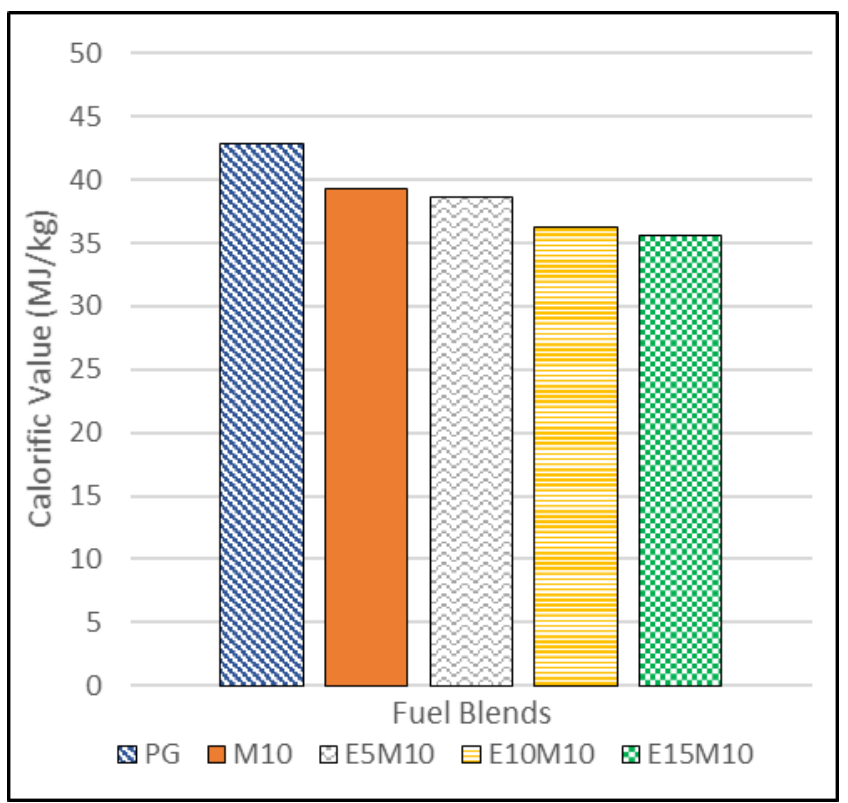

Fig. 4. $\mathrm{CV}$ variation for Methanol-Gasoline, GEM Blends and pure gasoline 


\subsection{Brake Specific Fuel Consumption}

Figure 5 indicates how BSFC varies for pure gasoline, M10, E5M10, E10M10 and E15M10 under variable loads between $25 \%$ to $75 \%$ rated power. In general, BSFC is found to decrease with increasing loads. It is also noticed that BSFC for pure gasoline and M10 is comparable across all applied load with slight variations. On average, pure gasoline has shown the lowest BSFC across all test conditions while M10 has shown an average increase of $1.6 \%$ as compared to pure gasoline. This slight increase is due to methanol having lower calorific value as compared to pure gasoline both per mass and volume. Consequently, the engine requires more methanol fuel to produce the same brake power as gasoline fuel. Other than that, fuel density is also a defining factor in higher BSFC for methanol-gasoline fuel since methanol possess higher density hence more mass is injected into the engine per volume at constant injection pressure [11]. Several researches have displayed similar relationship between gasoline and alcohols in general specifically methanol [11, 37, 45, 50]. Addition of ethanol at constant methanol concentration of M10 has resulted in remarkable BSFC increase as compared to pure gasoline with E5M10, E10M10 and E15M10 fuels displaying an average increase of $6.8 \%, 11.6 \%$, and $17.2 \%$ respectively. It is evident for each load condition, as ethanol concentration in a test fuel increases, BSFC also increases. It is explained that in relation to the case of M10 as discussed previously, although ethanol possesses much higher calorific value than methanol, it possesses significantly lower calorific value as compared to pure gasoline and hence as ethanol content is added into the blend, content of pure gasoline decreases thereby reducing overall calorific value of the blend as presented in the previous section.

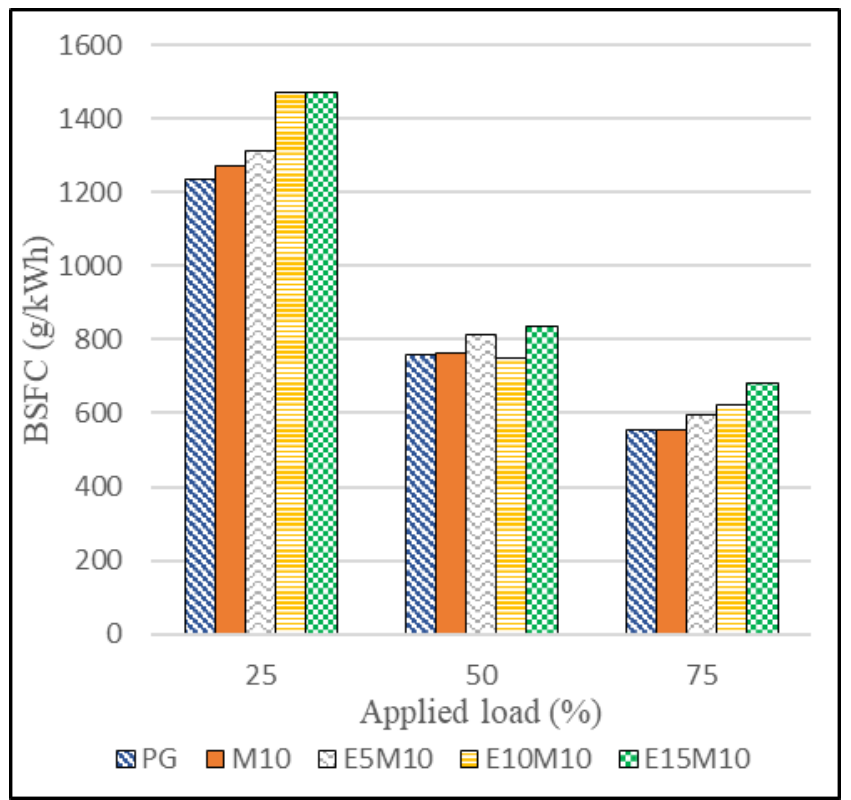

Fig. 5. Variation of BSFC for M10, GEM blends and pure gasoline under variable applied loads

Ultimately, E5M10, E10M10 and E15M10 possess reduced calorific value than pure gasoline and M10 thus requiring more fuel to produce the same brake power. Sileghem et al., [37] has reported similar trend for GEM blends compared to methanol and gasoline fuel. It is noted that at $50 \%$ load, E10M10 displays most reduced BSFC at $748.728 \mathrm{~g} / \mathrm{kWh}$. This trend is contrasting trends presented at $25 \%$ and $75 \%$ loads. This could be attributed to the fact that this study utilises commercial gasoline for blending with methanol and ethanol rather than iso-octane as utilised in several previous documented studies $[53,54]$. It is known that commercial gasoline contains additives in the form of 
metal deactivators and corrosion inhibitors, and although employed in a small concentration, it affects air-fuel mixing and burning process which in turn affects combustion characteristics, fuel economy, and engine-out emissions. Similar concerns are shared with Wang et al., [25].

\subsection{Brake Thermal Efficiency}

Figure 6 indicates how BTE varies for methanol-gasoline, GEM blends and pure gasoline under variable load condition. Under constant engine speed, BTE increases for all fuel blends as applied load increases. It is also found that on average, methanol-gasoline and GEM blends indicate higher BTE as compared to pure gasoline. E10M10 has shown the most improvement with an average of $9.4 \%$ increase as compared to pure gasoline. Meanwhile, M10, E5M10, and E15M10 displays an average of $8.4 \%, 3.8 \%$, and $2.4 \%$ increase respectively with reference to pure gasoline. Methanolgasoline and GEM blends possess higher BTE than pure gasoline due to methanol and ethanol fuels possess higher heat of vaporisation thereby producing sufficient cooling effect to overcome vapour effect in the working charge during fuel vaporisation at compression stroke [55]. On top of that, methanol and ethanol possess higher oxygen content which promotes a more complete combustion $[11,47]$. Moreover, addition of ethanol in fuel blends promotes faster combustion and a lower flame temperature as compared to pure gasoline; thus, heat loss at the combustion chamber is minimal therefore increasing thermal efficiency [27]. This trend has been highlighted in previous studies on methanol-gasoline blends $[23,24]$ as well as GEM blends [37, 39].

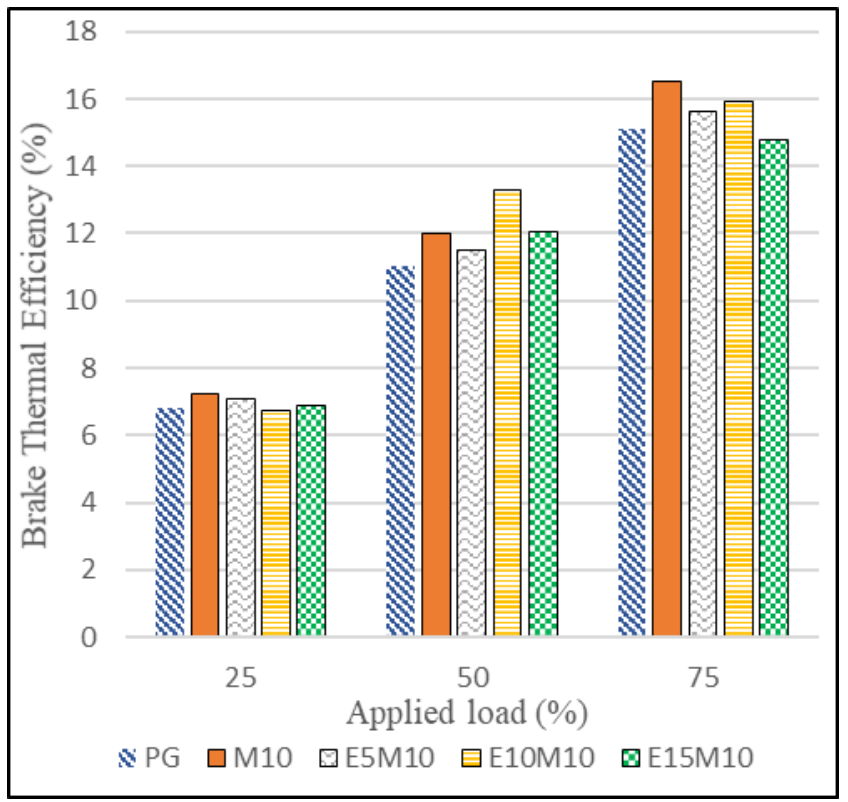

Fig. 6. Variation of BTE for M10, GEM blends and pure gasoline under variable applied loads

\subsection{CO Emissions}

Figure 7 presents variations of $\mathrm{CO}$ emissions for methanol-gasoline, GEM blends and pure gasoline across all tested engine loads measured in parts per million (ppm).

It is obvious that pure gasoline emits highest amount of CO with an average of $3990 \mathrm{ppm}$ across all tested loads. At $50 \%$ load, pure gasoline emitted maximum amount of $\mathrm{CO}$ at $4409 \mathrm{ppm}$. In contrast, E15M10 has produced the least CO with an average of $375 \mathrm{ppm}$ across all tested engine load. At $75 \%$ load, E15M10 emitted minimum amount of CO at 161 ppm. In general, methanol-gasoline and GEM 
blends displayed reduced average $\mathrm{CO}$ emissions as compared to pure gasoline. M10, E5M10, E10M10 and $\mathrm{E} 15 \mathrm{M} 10$ has shown an average of $39.4 \%, 58.4 \%, 56.7 \%$, and $90.6 \%$ decrease in CO emissions as compared to pure gasoline. Thus, there is a clear correlation between ethanol content and $\mathrm{CO}$ emissions whereby as ethanol concentration increases, CO emission decreases dramatically. This trend is expected due to the presence of oxygen in ethanol which assists in a more complete fuel combustion due to leaning effect $[24,29,38,56]$. Furthermore, ethanol and methanol possess increased laminar flame speed which also assists in more complete combustion $[11,57]$.

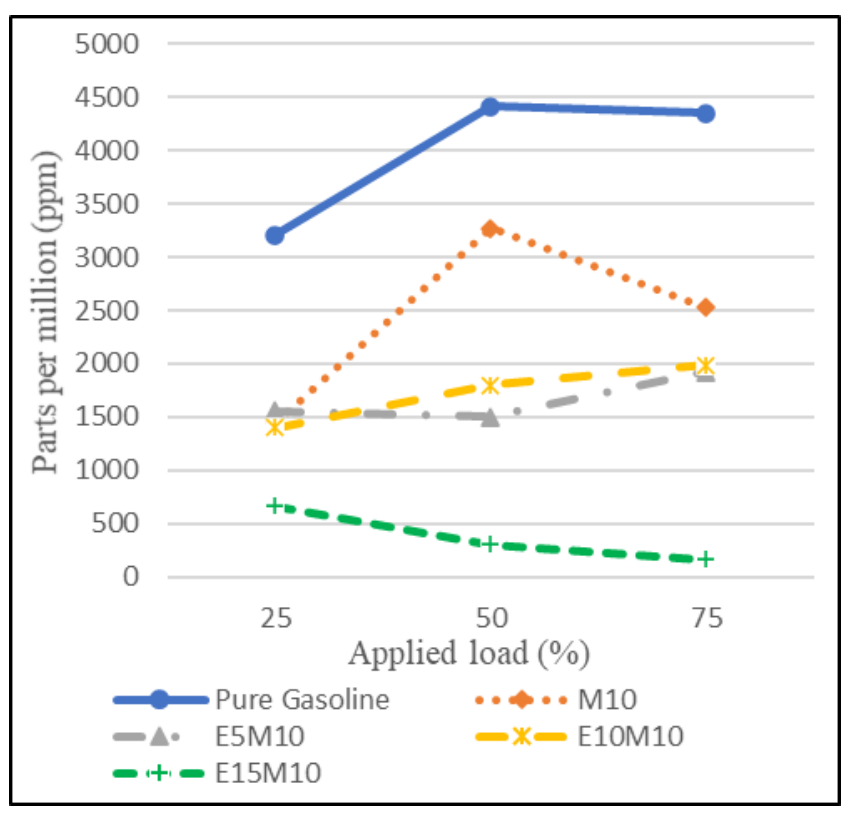

Fig. 7. Variation of $\mathrm{CO}$ emissions for M10, GEM blends and pure gasoline under variable loads

\section{7 $\mathrm{CO}_{2}$ Emissions}

Figure 8 shows the variation of $\mathrm{CO} 2$ emissions profile for methanol-gasoline, GEM blends and pure gasoline across variable loads measured in volume \%.

It is apparent from the results that by average, pure gasoline emits the least $\mathrm{CO}_{2}$ at $0.88 \%$ by volume. E10M10 has shown the highest increase of average $\mathrm{CO}_{2}$ emissions as compared to pure gasoline at $110 \%$ increase. Meanwhile, M10, E5M10 and E15M10 has shown average increase of $66 \%, 31.3 \%$, and $39.6 \%$ respectively. At $50 \%$ load, E10M10 has emitted the peak maximum of $3.04 \%$ of $\mathrm{CO} 2$. It can be deduced that at that instant, E10M10 fuel undergoes the most complete combustion in relation to other test fuels. This indicates that presence of oxygen in methanol and ethanol assist in producing leaning effect as discussed in the previous section, and enhances $\mathrm{CO}_{2}$ production [38] Therefore, combustion is efficient since more hydrocarbon is oxidised and useful energy is released as evident from BTE results where E10M10 achieves highest overall BTE at 50\% load. However, it is noted that $\mathrm{CO}_{2}$ emissions profile does not fully correlate to $\mathrm{CO}$ emissions profile where a clear correlation is present between alcohol content and CO emissions. For instance, it is apparent at $75 \%$ load, pure gasoline emits comparable amount of $\mathrm{CO}_{2}$ as $\mathrm{E} 5 \mathrm{M} 10$ and $\mathrm{E} 15 \mathrm{M} 10$ with emissions of $1.1 \%$, $1.0 \%$ and $0.91 \%$ respectively. It can be argued that while $\mathrm{CO}_{2}$ emissions should be opposite of $\mathrm{CO}$ emissions due to leaning effect, methanol-gasoline and GEM blends contain less carbon atoms as compared to pure gasoline hence reducing $\mathrm{CO}_{2}$ emissions. As the result, these two competing factors 
conflict each other leading to unclear correlation between $\mathrm{CO}$ and $\mathrm{CO}_{2}$ emissions. Similar findings have been reported by Costagliola et al., [29] in their research on bioethanol-gasoline blends.

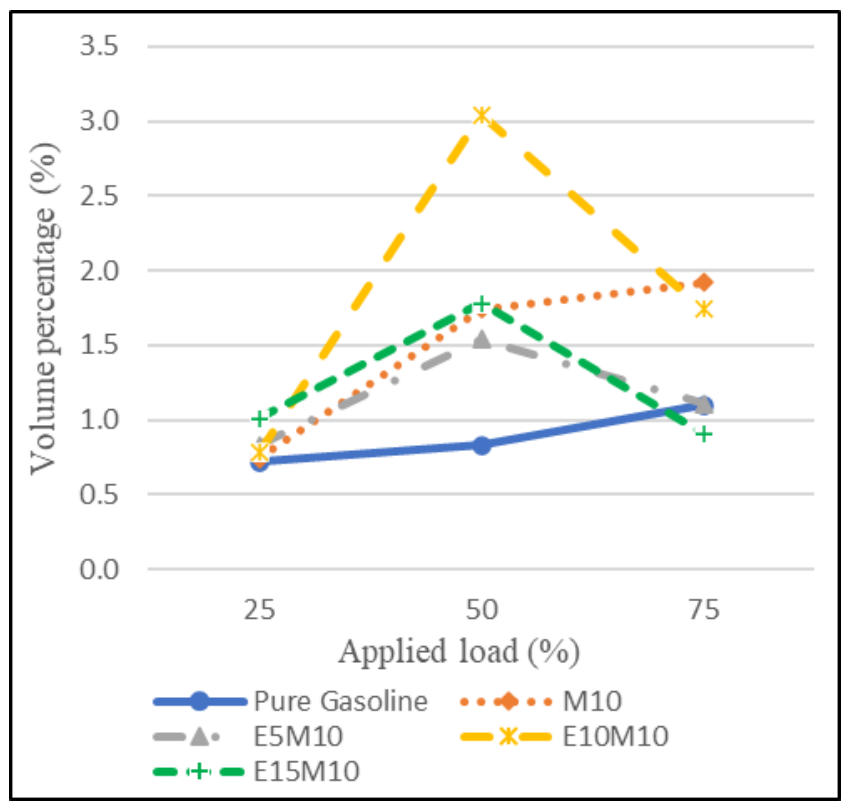

Fig. 8. Variation of $\mathrm{CO}_{2}$ emissions for $\mathrm{M} 10$, GEM blends and pure gasoline under variable loads

\subsection{NOx Emissions}

Figure 9 depicts variation of $\mathrm{NO}_{\mathrm{x}}$ emissions profile for methanol-gasoline, GEM blends and pure gasoline across variable loads in ppm. Pure gasoline is found to emit the least $\mathrm{NO}_{\mathrm{x}}$ across all test conditions at an average of $11.67 \mathrm{ppm}$. In general, methanol-gasoline and GEM blends emit higher $\mathrm{NO}_{x}$ than pure gasoline by an average of 1.7, 4.2, 6.7, and 5.8 times increment for M10, E5M10, E10M10 and E15M10 fuels respectively. It is explained that presence of oxygen atom in ethanol and methanol increases peak combustion temperature during combustion process [11] resulting in high in-cylinder temperature which is the main reason for $\mathrm{NO}_{x}$ formation in gasoline engines [40]. The results concur with several past research on $\mathrm{NO}_{x}$ emissions in alcohol-gasoline fuel blends [11, 40, $44,50]$. Nonetheless, the remarkable increase in $\mathrm{NO}_{x}$ emissions among GEM blends as seen in this research requires considerable attention in order to meet stringent European emissions standards. Previous investigations by Liu et al., [23] has found that utilisation of a three way catalytic converter (TWC) has shown some success in reducing $\mathrm{NO}_{\mathrm{x}}$ emissions of methanol-gasoline fuel by approximately $63 \%$ under low torque conditions and $90 \%$ under higher torque conditions. It is important to note that the engine setup used in this study does not encompass any exhaust gas treatment, and the authors believe that by undergoing exhaust gas treatment via TWC, $\mathrm{NO}_{\mathrm{x}}$ emissions could potentially decrease and therefore is an area of interest in further research on GEM blends. 


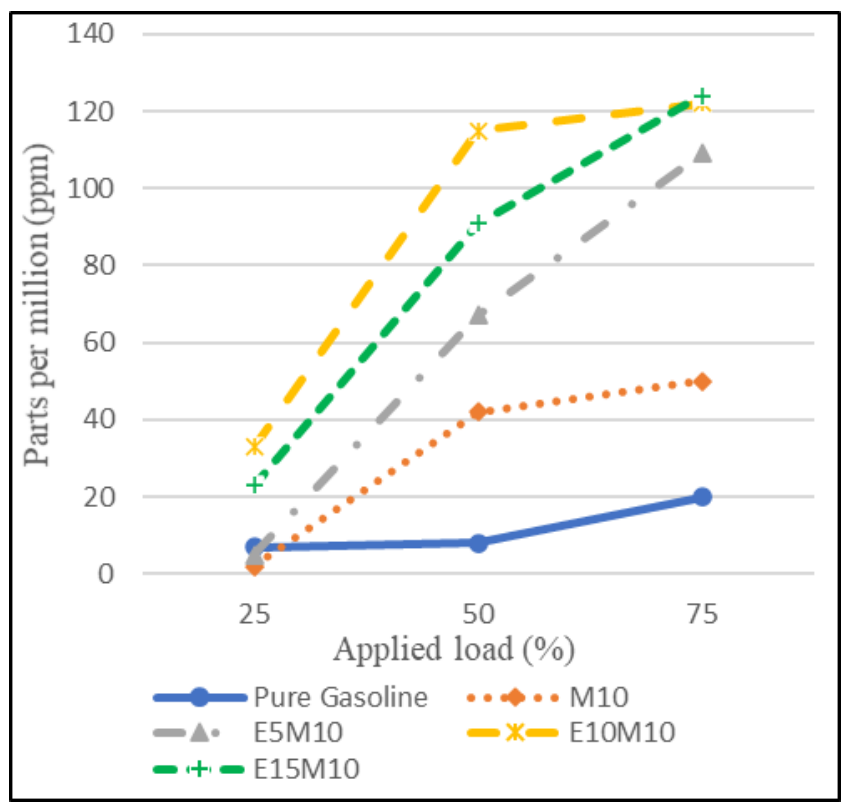

Fig. 9. Variation of NOx emissions for M10, GEM blends and pure gasoline under variable loads

\section{Conclusion}

In this research, ethanol additives were added at various ethanol blend ratio of 5 vol\%, 10 vol\% and 15 vol\%. to constant methanol-gasoline blend concentration of 10 vol\%. The resultant GEM blends of M10, E5M10, E10M10 and E15M10 were measured in terms of their physicochemical properties and compared with pure gasoline. These blends are then tested on a single cylinder SI engine in terms of engine performance and exhaust emissions at constant engine speed of $3000 \mathrm{rpm}$ and variable electrical loads of $25 \%, 50 \%$, and $75 \%$. The results are compared to that of pure gasoline. In short, the results of this research are summed up as per following

i. Methanol-gasoline and GEM blends have shown a remarkable increase in density and kinematic viscosity with reference to pure gasoline. E15M10 shows the highest increase of $10.7 \%$ and $18.7 \%$ in terms of density and kinematic viscosity respectively. However, methanol-gasoline and GEM blends possess lower calorific values compared to pure gasoline. E15M10 displays most reduction in calorific value at $16.9 \%$.

ii. Methanol-gasoline and GEM blends exhibit an increase in BTE with respect to pure gasoline. E10M10 presents highest average BTE improvement of 9.4\%. However, methanol-gasoline and GEM blends have resulted in increased BSFC compared to pure gasoline with E15M10 indicating highest BSFC increase at $17.2 \%$ on average. Emissions wise, methanol-gasoline and GEM blends displayed reduced $\mathrm{CO}$ emissions, increased $\mathrm{CO} 2$ emissions and higher NOx emissions as compared to pure gasoline. E15M10 improves $\mathrm{CO}$ emissions at $90.6 \%$ reduction, while E10M10 indicates highest increase of $\mathrm{CO} 2$ and NOx emissions at $110 \%$ and 6.7 times increment respectively.

iii. E10M10 has shown the most pronounced increase in terms of BTE while displaying the highest emission of $\mathrm{CO} 2$ and NOx. On the other hand, E15M10 has shown lowest CO emissions, despite having the highest average BSFC.

In a nutshell, GEM blends considered in this research have improved engine performance and reduced $\mathrm{CO}$ emissions. In particular, E10M10 blend improves engine performance as supported by increased $\mathrm{CO} 2$ emissions at the expense of heightened NOx emissions, while E15M10 improves CO emissions at the expense of fuel economy. 


\section{Acknowledgement}

The authors would like to express their sincerest gratitude towards Faculty of Mechanical Engineering, Universiti Teknologi MARA, Shah Alam for providing laboratory facilities, expertise, and continuous support necessary for the completion of this research. This research was funded by Fundamental Research Grant Scheme (FRGS) from the Malaysian Ministry of Higher Education (Grant No FRGS/1/2019/TK10/UITM/02/16)

\section{References}

[1] Rice, Ken, Bärbel Winkler, Peter Jacobs, Andrew G Skuce, John Cook, Sarah A Green, Rob Painting, et al. "Consensus on Consensus: A Synthesis of Consensus Estimates on Human-Caused Global Warming." Environmental Research Letters 11, no. 4 (2016): 048002. https://doi.org/10.1088/1748-9326/11/4/048002

[2] Davis, Stacy C., and Robert G. Boundy. Transportation Energy Data Book: Edition 37. 37th ed. Washington, D.C., 2019.

[3] Li, Ning, Tian Xia, and Andre E. Nel. "The Role of Oxidative Stress in Ambient Particulate Matter-Induced Lung Diseases and Its Implications in the Toxicity of Engineered Nanoparticles." Free Radical Biology and Medicine 44, no. 9 (2008): 1689-99. https://doi.org/10.1016/i.freeradbiomed.2008.01.028

[4] Abas, N., A. Kalair, and N. Khan. "Review of Fossil Fuels and Future Energy Technologies." Futures 69 (2015): $31-$ 49. https://doi.org/10.1016/i.futures.2015.03.003

[5] Geng, Peng, Erming Cao, Qinming Tan, and Lijiang Wei. "Effects of Alternative Fuels on the Combustion Characteristics and Emission Products from Diesel Engines: A Review." Renewable and Sustainable Energy Reviews 71, no. November 2016 (2017): 523-34. https://doi.org/10.1016/i.rser.2016.12.080

[6] Jazair, Wira, Syunsuke Kubo, Masazumi Takayasu, Tomoaki Yatsufusa, and Yoshiyuki Kidoguchi. "Performance and Emission Characteristics of a Diesel Engine Fueled by Rapeseed Oil Bio-Fuel." Jurnal Mekanikal, no. 33 (2011): 3239. https://jurnalmekanikal.utm.my/index.php/jurnalmekanikal/article/view/84/83

[7] IUPAC. Compendium of Chemical Terminology. 2nd ed., 1997.

[8] Gravalos, I., D. Moshou, Th Gialamas, P. Xyradakis, D. Kateris, and Z. Tsiropoulos. "Emissions Characteristics of Spark Ignition Engine Operating on Lower-Higher Molecular Mass Alcohol Blended Gasoline Fuels." Renewable Energy 50 (2013): 27-32. https://doi.org/10.1016/i.renene.2012.06.033

[9] Bilgin, Atilla, and Ismet Sezer. "Effects of Methanol Addition to Gasoline on the Performance and Fuel Cost of a Spark Ignition Engine." Energy and Fuels 22, no. 4 (2008): 2782-88. https://doi.org/10.1021/ef8001026

[10] Niven, Robert K. "Ethanol in Gasoline: Environmental Impacts and Sustainability Review Article." Renewable and Sustainable Energy Reviews 9, no. 6 (2005): 535-55. https://doi.org/10.1016/i.rser.2004.06.003

[11] Sharudin, Hazim, Nik Rosli Abdullah, G. Najafi, Rizalman Mamat, and H. H. Masjuki. "Investigation of the Effects of Iso-Butanol Additives on Spark Ignition Engine Fuelled with Methanol-Gasoline Blends." Applied Thermal Engineering 114 (2017): 593-600. https://doi.org/10.1016/j.applthermaleng.2016.12.017

[12] Methanol Institute. "Overview of Global Methanol Fuel Blending." In Trinidad and Tobago Methanol Fuel Blending Forum. Methanol Institute, 2019.

[13] Nakagawa, Hitoshi, Toshirou Harada, Toshimitsu Ichinose, Keiji Takeno, Shinji Matsumoto, Makoto Kobayashi, and Masayasu Sakai. "Biomethanol Production and CO 2 Emission Reduction from Forage Grasses, Trees, and Crop Residues." Japan Agricultural Research Quarterly 41, no. 2 (2007): 173-80. https://doi.org/10.6090/jarq.41.173

[14] Seddon, D. Advances in Clean Hydrocarbon Fuel Processing. Advances in Clean Hydrocarbon Fuel Processing. Woodhead Publishing Limited, 2011. https://doi.org/10.1533/9780857093783.4.363

[15] Bae, Choongsik, and Jaeheun Kim. "Alternative Fuels for Internal Combustion Engines." Proceedings of the Combustion Institute 36, no. 3 (2017): 3389-3413. https://doi.org/10.1016/i.proci.2016.09.009

[16] Petrou, Evangelos C., and Costas P. Pappis. "Biofuels: A Survey on Pros and Cons." Energy and Fuels 23, no. 2 (2009): 1055-66. https://doi.org/10.1021/ef800806g

[17] Balat, Mustafa. "Global Bio-Fuel Processing and Production Trends." Energy Exploration \& Exploitation 25, no. 3 (2007): 195-218. https://doi.org/10.1260/014459807782009204

[18] Renewable Fuels Association. "Annual World Fuel Ethanol Production (Mil. Gal.)," 2019.

[19] Awad, Omar I., R. Mamat, Obed M. Ali, N. A.C. Sidik, T. Yusaf, K. Kadirgama, and Maurice Kettner. "Alcohol and Ether as Alternative Fuels in Spark Ignition Engine: A Review." Renewable and Sustainable Energy Reviews 82, no. May 2017 (2017): 2586-2605. https://doi.org/10.1016/i.rser.2017.09.074

[20] Yusoff, M. N.A.M. "Comparative Study of Ethanol and Isobutanol As Gasoline Blend for Internal Combustion Engine Faculty of Engineering." University of Malaya, 2018.

[21] Patakova, Petra, Daniel Maxa, Mojmir Rychtera, Michaela Linhova, Petr Fribert, Zlata Muzikova, Jakub Lipovsky, et 
al. Perspectives of Biobutanol Production and Use. Biofuel's Engineering Process Technology, 2011. https://doi.org/10.5772/16464

[22] Zulkurnai, Fatin Farhanah, Norhidayah Mat Taib, Wan Mohd Faizal Wan Mahmood, and Mohd Radzi Abu Mansor. "Combustion Characteristics of Diesel and Ethanol Fuel in Reactivity Controlled Compression Ignition Engine" 2, no. 1 (2020): 1-13.

[23] Liu, Shenghua, Eddy R. Cuty Clemente, Tiegang Hu, and Yanjv Wei. "Study of Spark Ignition Engine Fueled with Methanol/Gasoline Fuel Blends." Applied Thermal Engineering 27, no. 11-12 (2007): 1904-10. https://doi.org/10.1016/i.applthermaleng.2006.12.024

[24] Yanju, Wei, Liu Shenghua, Li Hongsong, Yang Rui, Liu Jie, and Wang Ying. "Effects of Methanol/Gasoline Blends on a Spark Ignition Engine Performance and Emissions." Energy and Fuels 22, no. 9 (2008): 1254-59. https://doi.org/10.1021/ef7003706

[25] Wang, Xin, Yunshan Ge, Linlin Liu, Zihang Peng, Lijun Hao, Hang Yin, Yan Ding, and Junfang Wang. "Evaluation on Toxic Reduction and Fuel Economy of a Gasoline Direct Injection- (GDI-) Powered Passenger Car Fueled with Methanol-Gasoline Blends with Various Substitution Ratios." Applied Energy 157 (2015): 134-43. https://doi.org/10.1016/i.apenergy.2015.08.023

[26] Dai, Peipei, Yunshan Ge, Yongming Lin, Sheng Su, and Bin Liang. "Investigation on Characteristics of Exhaust and Evaporative Emissions from Passenger Cars Fueled with Gasoline/Methanol Blends.” Fuel 113 (2013): 10-16. https://doi.org/10.1016/i.fuel.2013.05.038

[27] Costa, Rodrigo C., and José R. Sodré. "Hydrous Ethanol vs. Gasoline-Ethanol Blend: Engine Performance and Emissions." Fuel 89, no. 2 (2010): 287-93. https://doi.org/10.1016/i.fuel.2009.06.017

[28] Costagliola, M. A., L. De Simio, S. lannaccone, and M. V. Prati. "Combustion Efficiency and Engine out Emissions of a S.I. Engine Fueled with Alcohol/Gasoline Blends." Applied Energy 111 (2013): 1162-71. https://doi.org/10.1016/i.apenergy.2012.09.042

[29] Costagliola, Maria Antonietta, Maria Vittoria Prati, Salvatore Florio, Pietro Scorletti, Daniele Terna, Paolo lodice, Dario Buono, and Adolfo Senatore. "Performances and Emissions of a 4-Stroke Motorcycle Fuelled with Ethanol/Gasoline Blends." Fuel 183, no. 2016 (2016): 470-77. https://doi.org/10.1016/i.fuel.2016.06.105

[30] Chen, Rong Horng, Li Bin Chiang, Chung Nan Chen, and Ta Hui Lin. "Cold-Start Emissions of an SI Engine Using Ethanol-Gasoline Blended Fuel." Applied Thermal Engineering 31, no. 8-9 (2011): $1463-67$. https://doi.org/10.1016/i.applthermaleng.2011.01.021

[31] Yücesu, Hüseyin Serdar, Tolga Topgül, Can Çinar, and Melih Okur. "Effect of Ethanol-Gasoline Blends on Engine Performance and Exhaust Emissions in Different Compression Ratios." Applied Thermal Engineering 26, no. 17-18 (2006): 2272-78. https://doi.org/10.1016/j.applthermaleng.2006.03.006

[32] Mittal, Nitesh, Robert Leslie Athony, Ravi Bansal, and C. Ramesh Kumar. "Study of Performance and Emission Characteristics of a Partially Coated LHR SI Engine Blended with N-Butanol and Gasoline." Alexandria Engineering Journal 52, no. 3 (2013): 285-93. https://doi.org/10.1016/j.aej.2013.06.005

[33] Gu, Xiaolei, Zuohua Huang, Jian Cai, Jing Gong, Xuesong Wu, and Chia Fon Lee. "Emission Characteristics of a SparkIgnition Engine Fuelled with Gasoline-n-Butanol Blends in Combination with EGR." Fuel 93, no. x (2012): 611-17. https://doi.org/10.1016/j.fuel.2011.11.040

[34] Elfasakhany, Ashraf. "Experimental Study on Emissions and Performance of an Internal Combustion Engine Fueled with Gasoline and Gasoline/n-Butanol Blends." Energy Conversion and Management 88 (2014): $277-83$. https://doi.org/10.1016/i.enconman.2014.08.031

[35] Venugopal, T., and A. Ramesh. "Experimental Studies on the Effect of Injection Timing in a SI Engine Using Dual Injection of N-Butanol and Gasoline in the Intake Port." Fuel 115 (2014): 295-305. https://doi.org/10.1016/i.fuel.2013.07.013.

[36] Turner, J.W.G., R. J. Pearson, E. Dekker, B. losefa, K. Johansson, and K. ac Bergström. "Extending the Role of Alcohols as Transport Fuels Using Iso-Stoichiometric Ternary Blends of Gasoline, Ethanol and Methanol." Applied Energy 102 (2013): 72-86. https://doi.org/10.1016/j.apenergy.2012.07.044

[37] Sileghem, L., A. Coppens, B. Casier, J. Vancoillie, and S. Verhelst. "Performance and Emissions of Iso-Stoichiometric Ternary GEM Blends on a Production SI Engine." Fuel 117, no. PART A (2013): $286-93$. https://doi.org/10.1016/j.fuel.2013.09.043

[38] Elfasakhany, Ashraf. "Investigations on the Effects of Ethanol-Methanol-Gasoline Blends in a Spark-Ignition Engine: Performance and Emissions Analysis." Engineering Science and Technology, an International Journal 18, no. 4 (2015): 713-19. https://doi.org/10.1016/j.jestch.2015.05.003.

[39] Nazzal, Ibrahim Thamer. "Experimental Study of Gasoline -Alcohol Blends on Performance of Internal Combustion Engine." European Journal of Scientific Research 52, no. 1 (2011): 15-22.

[40] Masum, B. M., H. H. Masjuki, M. A. Kalam, S. M. Palash, and M. Habibullah. "Effect of Alcohol-Gasoline Blends Optimization on Fuel Properties, Performance and Emissions of a SI Engine." Journal of Cleaner Production 86 
(2015): 230-37. https://doi.org/10.1016/j.jclepro.2014.08.032

[41] ASTM International. "Standard Test Method for Heat of Combustion of Liquid Hydrocarbon Fuels by Bomb Calorimeter (Reapproved 2007)." ASTM Standard D240-02, 2007, 1-9.

[42] ASTM International. "Standard Test Method for Kinematic Viscosity of Transparent and Opaque Liquids (and Calculation of Dynamic Viscosity)." ASTM Standard D445-06, 2006, 1-10.

[43] Heywood, John B. Internal Combustion Engine Fundamentals. McGraw-Hill, 1988.

[44] Zaharin, M. S.M., N. R. Abdullah, H. H. Masjuki, Obed M. Ali, G. Najafi, and Talal Yusaf. "Evaluation on Physicochemical Properties of Iso-Butanol Additives in Ethanol-Gasoline Blend on Performance and Emission Characteristics of a Spark-Ignition Engine." Applied Thermal Engineering 144 (2018): 960-71. https://doi.org/10.1016/i.applthermaleng.2018.08.057

[45] Eyidogan, Muharrem, Ahmet Necati Ozsezen, Mustafa Canakci, and Ali Turkcan. "Impact of Alcohol-Gasoline Fuel Blends on the Performance and Combustion Characteristics of an SI Engine." Fuel 89, no. 10 (2010): 2713-20. https://doi.org/10.1016/i.fuel.2010.01.032

[46] Awad, Omar I., R. Mamat, Thamir K. Ibrahim, Ali Thaeer Hammid, I. M. Yusri, Mohd Adnin Hamidi, Ali M. Humada, and A. F. Yusop. "Overview of the Oxygenated Fuels in Spark Ignition Engine: Environmental and Performance." Renewable and Sustainable Energy Reviews 91, no. March (2018): 394-408. https://doi.org/10.1016/j.rser.2018.03.107

[47] Balki, Mustafa Kemal, Cenk Sayin, and Mustafa Canakci. "The Effect of Different Alcohol Fuels on the Performance, Emission and Combustion Characteristics of a Gasoline Engine." Fuel 115 (2014): 901-6. https://doi.org/10.1016/i.fuel.2012.09.020

[48] Canakci, Mustafa, Ahmet Necati Ozsezen, Ertan Alptekin, and Muharrem Eyidogan. "Impact of Alcohol-Gasoline Fuel Blends on the Exhaust Emission of an SI Engine." Renewable Energy 52, no. x (2013): 111-17. https://doi.org/10.1016/i.renene.2012.09.062

[49] Yusri, I. M., R. Mamat, G. Najafi, A. Razman, Omar I. Awad, W. H. Azmi, W. F.W. Ishak, and A. I.M. Shaiful. "Alcohol Based Automotive Fuels from First Four Alcohol Family in Compression and Spark Ignition Engine: A Review on Engine Performance and Exhaust Emissions." Renewable and Sustainable Energy Reviews 77, no. October 2015 (2017): 169-81. https://doi.org/10.1016/j.rser.2017.03.080

[50] Zaharin, M. S.M., N. R. Abdullah, M. Imran Dahalan, Hazim Sharudin, A. R. Asiah, and M. Beriache. "Experimental Study on the Effects of Methanol and Ethanol on Gasoline Engine Performance and Exhaust Emissions." Journal of Mechanical Engineering SI 2, no. 2 (2017): 27-44.

[51] Sharudin, Hazim, Nik Rosli Abdullah, Fairuza Shahira, M. Hazimi Ismail, N.I. Ismail, and A.S. Abdullah. "Study on Fuel Characterization of Methanol-Ethanol Additive in Gasoline Blends." Proceedings of Mechanical Engineering Research Day, no. May 2018 (2018): 18-19.

[52] Taib, Norhidayah Mat, Mohd Radzi Abu Mansor, Wan Mohd Faizal Wan Mahmood, Fais Ahmad Shah, and Nik Rosli Nik Abdullah. "Investigation of Diesel-Ethanol Blended Fuel Properties with Palm Methyl Ester as Co-Solvent and Blends Enhancer." MATEC Web of Conferences 90 (2016). https://doi.org/10.1051/matecconf/20179001080

[53] Oh, Heechang, Choongsik Bae, and Kyoungdoug Min. "Spray and Combustion Characteristics of Ethanol Blended Gasoline in a Spray Guided Disi Engine under Lean Stratified Operation." SAE Technical Papers 3, no. 2 (2010): 21322. https://doi.org/10.4271/2010-01-2152

[54] Silva, A. da, J. Hauber, L. R. Cancino, and K. Huber. "The Research Octane Numbers of Ethanol-Containing Gasoline Surrogates." Fuel 243, no. August 2018 (2019): 306-13. https://doi.org/10.1016/i.fuel.2019.01.068

[55] Al-Hasan, M. "Effect of Ethanol-Unleaded Gasoline Blends on Engine Performance and Exhaust Emission." Energy Conversion and Management 44, no. 9 (2003): 1547-61. https://doi.org/10.1016/S0196-8904(02)00166-8

[56] Turner, Dale, Hongming Xu, Roger F. Cracknell, Vinod Natarajan, and Xiangdong Chen. "Combustion Performance of Bio-Ethanol at Various Blend Ratios in a Gasoline Direct Injection Engine." Fuel 90, no. 5 (2011): 1999-2006. https://doi.org/10.1016/i.fuel.2010.12.025

[57] Yusoff, M. N.A.M., N. W.M. Zulkifli, H. H. Masjuki, M. H. Harith, A. Z. Syahir, L. S. Khuong, M. S.M. Zaharin, and Abdullah Alabdulkarem. "Comparative Assessment of Ethanol and Isobutanol Addition in Gasoline on Engine Performance and Exhaust Emissions." Journal of Cleaner Production 190 (2018): 483-95. https://doi.org/10.1016/j.jclepro.2018.04.183 